\title{
Comparative Serological Studies Between a Newly Isolated Halophilic Leptospira and Two Other Leptospiras Isolated from Brackish Water
}

\author{
M. CINCO, M. TAMARO, G. D. ROTTINI, and C. MONTI-BRAGADIN \\ Institute of Microbiology, University of Trieste, Trieste, Italy
}

\begin{abstract}
A leptospiral strain designated "Muggia" was isolated from seawater. It was found to be halophilic, growing only in media prepared with seawater; otherwise it was characteristic of "saprophytic" (biflexa) leptospiras. By the use of extensive cross-agglutination tests, it was compared with two other brackishwater, but nonhalophilic, leptospiral isolates, $8 \mathrm{M}$ and $11 \mathrm{M}$. The three strains were serologically distinct from each other. Strain $8 \mathrm{M}$ was found to belong to a new serotype, which was designated timavo. Strains Muggia and $11 \mathrm{M}$ cross-reacted with various biflexa serotypes but could not be definitively identified with any known serotype. They may also represent new serological types.
\end{abstract}

The isolation of leptospiras from seawater has been reported a number of times in the past $(1-3,9,10)$. However, none of these microorganisms required a medium containing an unusual salt concentration for growth. In the present paper, we report the isolation of a strain of Leptospira which shows a unique salt requirement for growth.

For the isolation of this strain, $250 \mathrm{ml}$ of seawater, drawn from the Adriatic Sea near Trieste (Bay of Muggia), was divided into 70 samples. Each sample was inoculated in Zuelzer (10) medium prepared with seawater with a salt concentration of $3.5 \%$. After 15 days of incubation at $20 \mathrm{C}$, leptospiras were demonstrated in 19 of the 70 samples by dark-field microscopy.

By filtration of the 19 positive samples through a membrane filter $(0.22 \mu \mathrm{m}$; Millipore Corp.) and serial passage in Korthof-Babudieri medium in which seawater was substituted for distilled water, a strain of Leptospira, which we designated "Muggia," was isolated, apparently in pure culture, from one of the samples. An antiserum prepared against the 6th-passage organisms completely suppressed the growth of the first isolate. This finding provided strong presumptive evidence that the culture was composed of organisms belonging to only one serotype (7). Strain Muggia is resistant to various growth inhibitors of the pathogenic leptospiras: growth was not inhibited by sodium bicarbonate $(1 \mathrm{mg} / \mathrm{ml})(8), 8$-azaguanine $(200 \mu \mathrm{g} / \mathrm{ml})(6)$, or copper sulfate $(10$ $\mu \mathrm{g} / \mathrm{ml}$ ) (5). Electron microscopy of strain Muggia showed a morphology typical of members of the genus Leptospira. Thin sections (Fig. 1,2) revealed the presence of: an outer sheath with three layers (two dense and one light); a cell wall-membrane complex, $6 \mathrm{~nm}$ wide, with two dense layers and a light, intermediate one; and finally an axial filament 0.01 to $0.02 \mu \mathrm{m}$ in diameter.

The new leptospiral strain and two strains not yet classified, $8 \mathrm{M}$ and $11 \mathrm{M}$, were compared with the reference strains of all of the Leptospira serotypes belonging to the "biflexa" complex by using the standard cross-agglutination and cross-absorption tests (according to the WHO/FAO rules on leptospiras, WHO/FAO Technical Rep. no. 380). Strains $8 \mathrm{M}$ and $11 \mathrm{M}$ were isolated from brackish water and have no special salt requirement for growth (3). The results of the cross-agglutination tests are given in Table 1, in which only the strains that showed some degree of reactivity with the three strains under study are reported.

The three strains shared no major agglutinogens. Strain $8 \mathrm{M}$ had antigenic affinities with serotype tredici strain AM13, but was anti- 


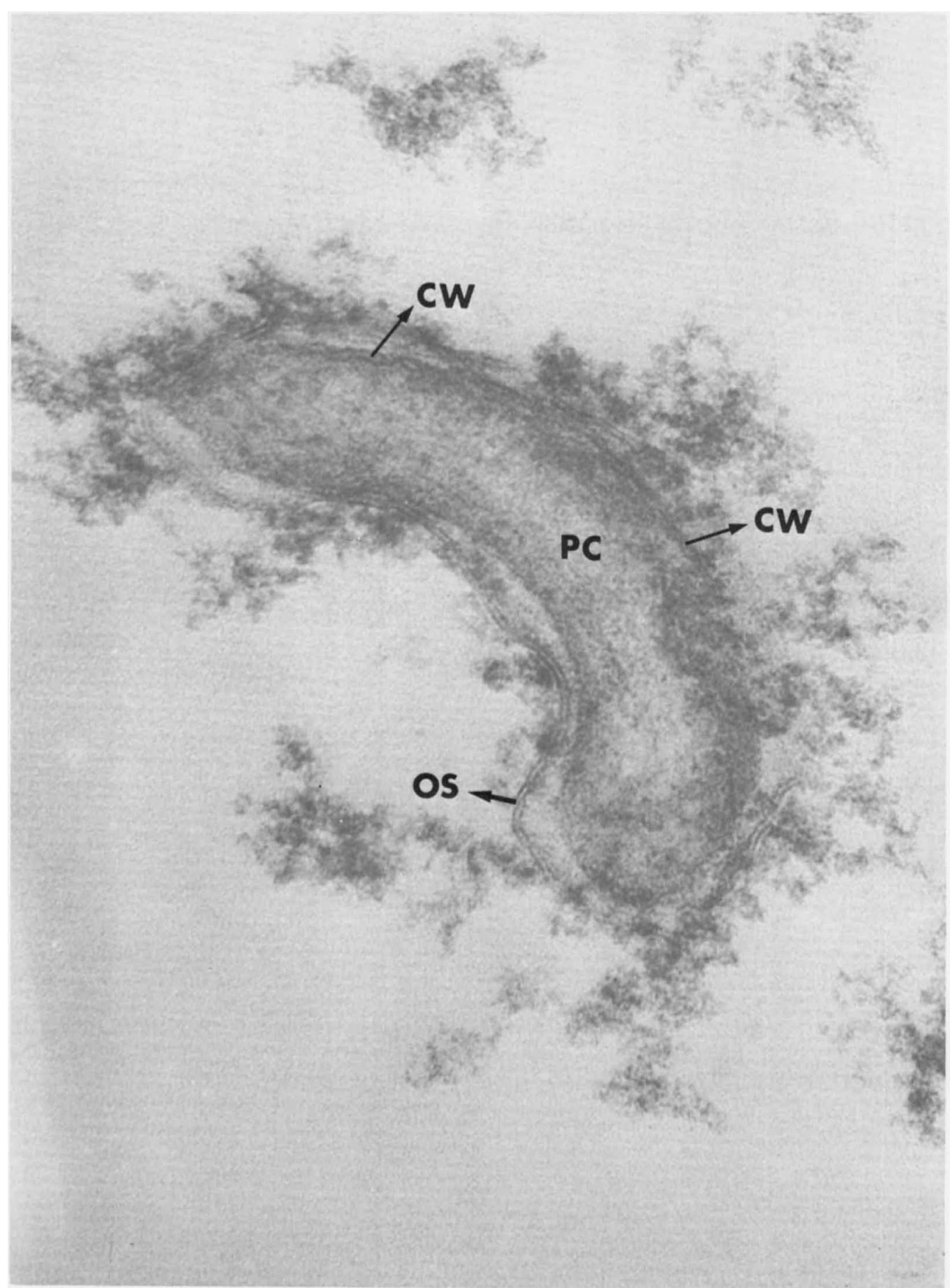

Fig. 1. Thin section of a cell of strain Muggia fixed in $1 \% \mathrm{OsO}_{4}$. Abbreviations: $O S$, outer sheath; PC, protoplasmic cylinder; $C W$, cell-wall membrane complex. $\times 307,800$. 
genically distinct from this strain on the basis of cross-agglutinin-adsorption test findings. Accordingly, strain $8 \mathrm{M}$ represents a new serotype, which we designate timavo and which can be grouped in the Holland serogroup (comprises tredici, roma, and holland). Strains Muggia and $11 \mathrm{M}$ could not be classified into any of the currently recognized serogroups, and they may represent new serological types.

Strain Muggia proved to be halodependent.

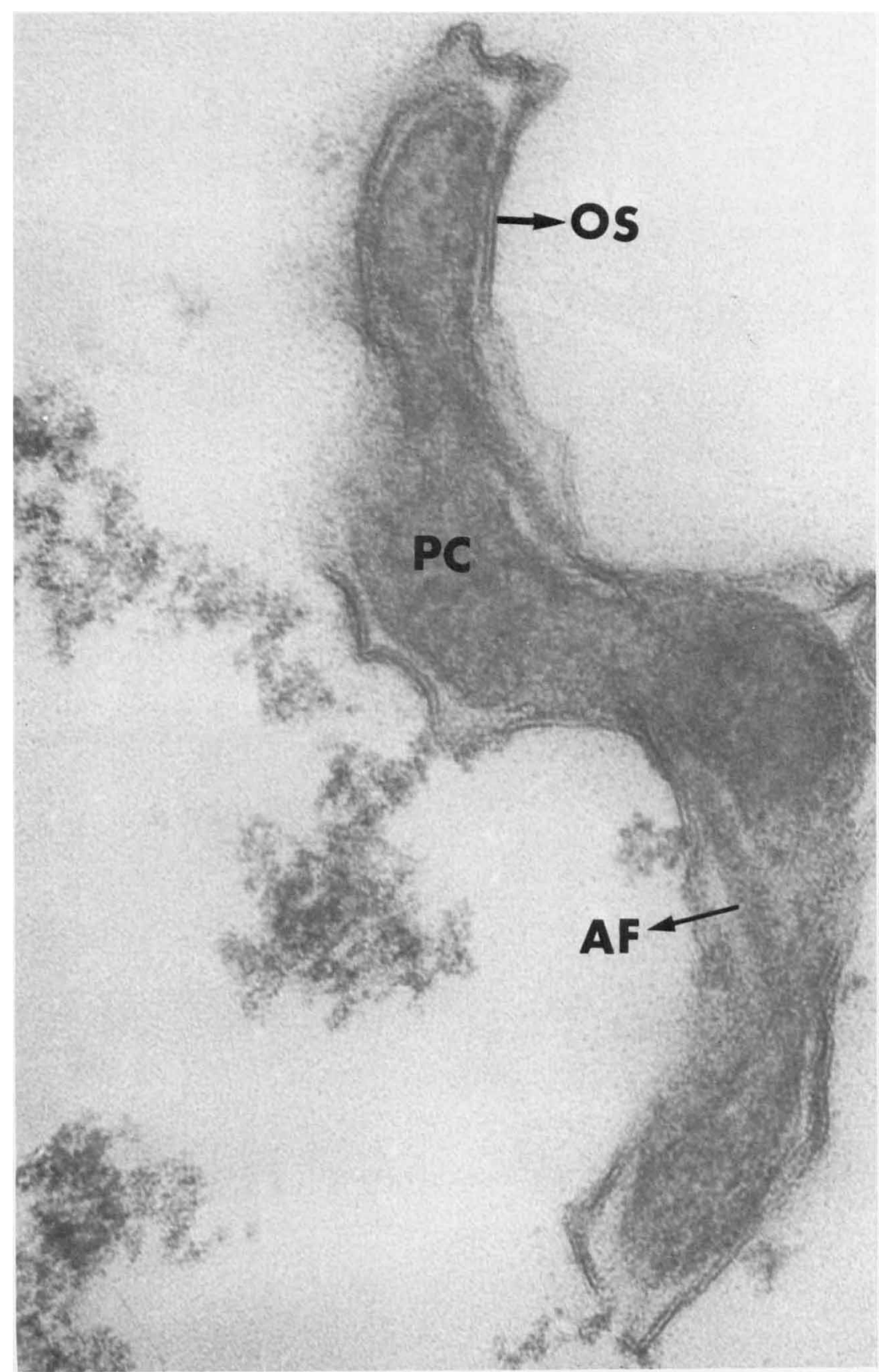

Fig. 2. Thin section of a cell of strain Muggia. Abbreviations: AF, axial filament; $O S$, outer sheath; PC, protoplasmic cylinder. $\times 239,400$. 
TABLE 1. Cross-agglutination tests between strains Muggia, $8 M$, and $11 M$ and reference strains of leptospiral serotypes having antigens in common

\begin{tabular}{|c|c|c|c|c|c|c|c|}
\hline \multirow{3}{*}{$\begin{array}{l}\text { Leptospiral } \\
\text { serotype }^{\alpha}\end{array}$} & \multirow[b]{3}{*}{ Strain } & \multicolumn{6}{|c|}{ Titers $^{b}$ ( $\%$ of homologous titer) } \\
\hline & & \multicolumn{2}{|c|}{ Muggia } & \multicolumn{2}{|c|}{$8 \mathrm{M}$} & \multicolumn{2}{|c|}{$11 \mathrm{M}$} \\
\hline & & Antigen & Antiserum & Antigen & Antiserum & Antigen & Antiserum \\
\hline \multirow[t]{3}{*}{ timavo } & Muggia & 100 & & 5 & 0.2 & 1 & 0.1 \\
\hline & $8 \mathrm{M}$ & 0.2 & 5 & 100 & & 1 & 2 \\
\hline & $11 \mathrm{M}$ & 0.1 & 1 & 2 & 1 & 100 & \\
\hline tredici & AM13 & 1 & 50 & 50 & 50 & 0 & 10 \\
\hline roma & AM6 & 0 & 10 & 0.5 & 10 & 1 & 100 \\
\hline holland & WaZH & 0 & 2 & 100 & 5 & 2 & 0.5 \\
\hline pulpudeva & Bulgaria 6 & 0 & 0 & 0 & 5 & 0 & 1 \\
\hline farneti & Farneti & 1 & 0 & 5 & 0.1 & 10 & 10 \\
\hline rupino & RPE & 0.1 & 0 & 1 & 0.2 & 1 & 0.1 \\
\hline aurisina & Aurisina & 10 & 0.2 & 0.5 & 0 & 2 & 0.1 \\
\hline basovizza & Basovizza & 0 & 0 & 0 & 0 & 0.1 & 0 \\
\hline doberdò & Doberdò 1 & 0 & 0 & 10 & 0.2 & 1 & 0 \\
\hline acquamarcia & AM20 & 0.2 & 2 & 10 & 10 & 10 & 0.2 \\
\hline
\end{tabular}

${ }^{a}$ Cross-reactions with 17 biflexa serotypes were negative.

${ }^{b}$ Homologous titers ranged from 1:50,000 to $1: 100,000$.

TABLE 2. Results of cross-agglutinin-absorption tests between leptospiral strains $8 M$ and $A M 13$

\begin{tabular}{c|l|r|r}
\hline \multirow{2}{*}{$\begin{array}{c}\text { Anti- } \\
\text { serum }\end{array}$} & \multicolumn{1}{|c|}{ Treatment } & \multicolumn{2}{c}{$\begin{array}{c}\text { Reciprocal of titer } \\
\text { with antigen }\end{array}$} \\
\cline { 3 - 4 } & \multicolumn{1}{|c}{$8 \mathrm{M}$} & \multicolumn{1}{|c}{ AM13 } \\
\hline \multirow{2}{*}{$8 \mathrm{M}$} & None & 50,000 & 25,000 \\
& Adsorbed with 8M & $<500$ & $<500$ \\
& Adsorbed with AM13 & 25,000 & 500 \\
AM13 & None & 50,000 & 100,000 \\
& Adsorbed with 8M & $<1,000$ & 100,000 \\
& Adsorbed with AM13 & $<1,000$ & $<1,000$ \\
\hline
\end{tabular}

Indeed, the doubling time of a culture of this strain in Korthof-Babudieri seawater medium was about 16 to $18 \mathrm{~h}$, and a maximal concentration of $2 \times 10^{8}$ cells $/ \mathrm{ml}$ was reached after 10 days of incubation at $30 \mathrm{C}$. No growth was observed in the same medium prepared with distilled water. On the contrary, an inoculum of $10^{7}$ cells $/ \mathrm{ml}$ of strain Muggia was lysed in such a medium, as judged by the fact that no cells were observed by dark-field microscopy of the inoculated medium after 48 $h$ of incubation at $30 \mathrm{C}$. Limited growth was observed in Korthof-Babudieri medium prepared with $50 \%$ seawater and $50 \%$ distilled water. It has recently been demonstrated that strain Muggia shows a specific $\mathrm{NaCl}$ requirement for growth (4).

\section{ACKNOWLEDGMENT}

We are grateful to Maria Rosa Soranzo for the electron micrographs.

\section{REPRINT REQUESTS}

Address reprint requests to: Dr. Marina Cinco, Institute of Microbiology, University of Trieste, Trieste, Italy.

\section{LITERATURE CITED}

1. Babudieri, B. 1969. A study of two strains of saprophytic leptospiras isolated in the Iran Region of the Caspian Sea. Arch. Inst. Razi 21:17-20.

2. Babudieri, B., and I. Archetti. 1947. Le leptospire acquicole e la loro costituzione antigenica. Rend. Ist. Super. Sanita (Ital. Ed.) 10:962.

3. Castelli, M. 1969. Presenza di leptospire in acqua marina. Atti $\mathbf{V}^{\mathbf{0}}$ Congr. Naz. Soc. Ital. Parass. 11:3741.

4. Cinco, M., and B. Babudieri. 1973. Isolation and characteristics of a halophilic strain of leptospira. Int. Symp. Leptospiroses. Bratislava.

5. Füzi, M., and R. Csoka. 1960. Die Differentierung der pathogenen und saprophytischen Leptospiren mittels eines kupersulfat Test. Zentralbl. Bakteriol. Parasitenk. Infektionskr. Abt. 1. Orig. 179:231.

6. Johnson, R. C., and P. Rogers. 1964. Differentiation of pathogenic and saprophytic leptospires with 8-azaguanine. J. Bacteriol. 88:1818-1623.

7. Magliocchetti-Lombi, P., and B. Babudieri. 1968. 
Ricerche su colture associate di leptospire. Ann. Ist. Super. Sanita 4:291-304.

8. Mazzonelli, I., and M. Castellani. 1968. Efecto del bicarbonato de sodio en la diferenciaciòn de leptospiras saprofitas y patogenas. Vet. (UNNE) 4:3-30.

9. Zuelzer, M. 1922. Freilebende Wasserspirochaeten als Krankheitserreger. Zentralbl. Bakteriol. Parasitenk Infektionskr. Abt. 1: Orig. 89:171-176.

10. Zuelzer, M. 1925. Ueber die Kultivierung mariner Spirochaeten mit einigen Bemerkungen zur Zuechtung der Spirochaeta obermeieri. Zentralbl. Bakteriol. Parasitenk. Infektionskr. Abt. 1: Orig. 96:424-427. 